\title{
Alternative Weed Control Methods during Grape Establishment in the United States Upper Midwest
}

\author{
John Stenger, Harlene Hatterman-Valenti \\ Plant Sciences, North Dakota State University, Fargo, USA \\ Email: john.stenger@ndsu.edu,h.hatterman.valenti@ndsu.edu
}

Received 12 May 2016; accepted 14 June 2016; published 17 June 2016

Copyright (C) 2016 by authors and Scientific Research Publishing Inc.

This work is licensed under the Creative Commons Attribution International License (CC BY). http://creativecommons.org/licenses/by/4.0/

(c) $\underset{\mathrm{EY}}{0}$ Open Access

\begin{abstract}
A field experiment was conducted to determine the effects of three mulches (straw, landscape fabric, and woodchip) and a single spring herbicide application (combination of oryzalin, flumioxazin, and glyphosate) on annual weed control and grapevine establishment in North Dakota. Vine growth, bud-break timing, bud hardiness and soil conditions were monitored to determine weed control method effects on vine progress. More consistent yellow foxtail (Setaria glauca L.) control occurred in mulched plots compared to plots treated with herbicide, particularly late in the season. In 2009, vines in mulched plots' bud-break date were up to five days later when compared to vines grown in herbicide treated plots. However, no differences were observed in the spring of 2010. Overall, differences in growth rate were due to cultivar differences and not weed control methods. Results suggest that any of the three mulches could be used for annual weed control in northern vineyards during establishment as they offered at least as much weed control as the herbicide control and did not adversely affect vine establishment. However, continued research is needed to determine if mulches will alter fruit yield and quality upon vine maturation and together influence winter dieback of vines.
\end{abstract}

\section{Keywords}

Vitis, Hybrid, Floor Management, Herbicide, Mulch

\section{Introduction}

Weed control must be implemented effectively without negatively affecting vine growth for successful establishment of grapevines in the Upper Midwest. Weed interference reduces grapevine vigor through competition 
for nutrients, space and water. Ineffective weed control after transplanting may delay establishment, flowering, and fruit production [1]. Weed competition also can reduce plant vigor and increase winter dieback [2]. Successful weed control after transplanting and during establishment can result in a quicker return on investment by influencing the interval before a vineyard becomes profitable.

Organic and synthetic mulches have been utilized for weed control for many years and in many cropping and ornamental situations [3]-[5]. Organic mulches have also been considered for vineyard weed control in the Eastern United States [6]. However, mulch effectiveness as a weed control agent and its effects on vine growth have not been assessed in emerging viticulture regions such as North Dakota. Mulches not only act to suppress weeds, but may improve soil conditions by increasing soil water content, reducing soil erosion, and decreasing soil compaction [7]. However, mulches may also alter the microclimate, soil properties, physiology, and phenology in plants [8] [9]. These alterations in vine physiology could result in deleterious consequences for North Dakota vineyards.

Synthetic mulches serve as an alternative to organic mulches as weed suppressants, however, their effect on soil conditions may vary. Soil temperatures and moisture contents recorded biweekly for one year under landscape fabrics varied more than those recorded under organic mulches [3]. Glover et al. compared conventional, integrated, and organic apple production systems on soil physical, chemical, and biological properties [10]. The authors stated that the organic method, which consisted of one year of bark mulch followed by two years of landscape fabric, resulted in lower soil bulk densities and generally improved biological soil properties compared to the conventional or herbicide weed control method. Soil quality factors measured were slightly better in the integrated method, which consisted of one year of bark mulch followed by yearly herbicide applications. However, this would require the additional cost of the yearly applications.

The objectives of this study were to compare organic and synthetic mulch efficacy to the standard herbicide weed control method used for the region and to determine how vine growth and winter hardiness after transplanting were influenced by weed control methods.

\section{Materials and Methods}

\subsection{Trial Location}

An experimental vineyard was established at a North Dakota Experiment Station research site in Richland County, ND on July 25, 2007. The trial was planted on a Matador-Delamere-Wyndmere fine sandy loam [11]. The experimental vineyard was arranged as a randomized complete block design with a split-plot arrangement and three replications. Main-plots were randomized within each replication and consisted of four in-row weed control methods (straw mulch, woodchip mulch, landscape fabric, or a single herbicide application) that spanned eight vines and covered an area of $9.6 \mathrm{~m}$ by $1.2 \mathrm{~m}$. Sub-plots were randomized within each main-plot and consisted of one non-grafted cold-climate, $V$. riparia derived, hybrid grape cultivar (St. Croix) and three non-grafted cold-climate, V. riparia derived, advanced selections from two breeding programs (DM 8521, MN 1200, and MN 1131). Experimental units consisted of two adjacent vines of a single randomly assigned cultivar.

Plants were grown one year in $11.4 \mathrm{~L}$ containers prior to transplanting. Transplanted vines were kept clean cultivated and watered twice after transplanting. No additional irrigation was provided for the remainder of the experiment. Vines were trellised on a high cordon system. Vineyard rows were established in a north to south orientation. Plants were spaced $2.4 \mathrm{~m}$ apart in rows spaced $3.1 \mathrm{~m}$ apart. Row middles were maintained as bare ground with a combination of tillage and spot applications of glyphosate at $0.87 \mathrm{~kg}$ ae/ha for perennial weeds (Roundup Weather Max®, Monsanto Company, St. Louis, MO). Spot applications of glyphosate at the same rate previously mentioned were also utilized to control perennial weed species, Canada thistle (Cirsium arevense L.) and field horsetail (Equisetum arvense L.), within all plots. Weed control treatments were initially applied in the spring of 2008. Data were collected for the growing seasons of 2008 and 2009. Dormant season data were collected in the springs of 2009 and 2010.

\subsection{Weed Control Treatments}

Both organic (straw and woodchip) and synthetic (landscape fabric) mulches were tested along with an herbicide application. Straw mulch was obtained as baled straw from a wheat crop grown the previous year and was applied to a thickness of $10 \mathrm{~cm}$. Woodchip mulch, composed of hardwood deciduous species, was obtained from a 
municipal source and applied to a thickness of $10 \mathrm{~cm}$. A fiber based landscape fabric was initially applied and then reinforced with a heavier $32 \mathrm{~mm}$ woven polypropylene fabric (Pro5 Weed Barrier ${ }^{\mathrm{TM}}$, Dewitt Company Inc., Sikeston, MO) on May 26, 2008 due to observed seed germination and weed growth under the initial fabric. Lastly, herbicides were applied as a single spring application of oryzalin at $2.2 \mathrm{~kg}$ ai/ha (Surflan ${ }^{\circledR}$, Dow AgroSciences LLC, Indianapolis, IN), flumioxazin at $0.14 \mathrm{~kg}$ ai/ha (Chateau ${ }^{\circledR}$, Valent U.S.A. Corporation, Walnut Creek, CA), and glyphosate at $0.87 \mathrm{~kg}$ ae/ha (Roundup PowerMax ${ }^{\mathrm{TM}}$, Monsanto Company, 800 North Lindbergh Boulevard, St. Louis, MO). Herbicides were selected to give contact as well as residual control of a broad range of annual, biennial, and perennial weed species. All treatments were applied on May 1, 2008. Straw mulch, woodchip mulch, and herbicides were reapplied May 2, 2009.

\subsection{Evaluation}

Annual weed control was evaluated twice per season at 10 and 20 weeks after application (July and September). Weed control was quantified as percent control by visual inspection compared to weed presence in an untreated plot margin near the treated row where 0 equated to no control and 100 indicated complete plant death or no plants present. Percentages were taken as a single main-plot value.

Plant growth was evaluated as vine shoot length and biomass production through dormant pruning weight. Each measure was averaged for the two vines within each sub-plot for analysis. Plant shoot lengths were measured during the dormant season as the length of the combined trunk and cordon from ground level. Dormant pruning weight was determined as the total fresh weight of one-year-old wood removed. In both years, each vine was pruned under the same goals of removal of dead material, trunk and cordon establishment, reduction in the number of trunks, and removal of undesirable lateral branches.

Effects on vegetative bud-break timing were monitored as the number of Julian days prior to the first unfurled leaf. Values were averaged over the two vines within each cultivar subplot for analysis.

Bud hardiness was evaluated each spring as the number of viable primary buds in a 50 bud sample taken from 10 random stems during dormant pruning. Randomly selected buds were sampled from stems with different diameters and from different positions in order to be representative of the entire vine. Viable buds were determined as buds that retained green tissue in the primary bud [12] [13]. Primary buds that were brown were considered not viable.

Soil temperature was monitored using thermistors (Decagon Devices Inc., Pullman, WA) and soil water content was monitored using soil probes (EC-10, Decagon Devices Inc., Pullman, WA) with periodic recording after calibration for the soil type. Thermistors and soil water content probes were placed in the center of each main-plot at a depth of $15 \mathrm{~cm}$. Temperature and moisture content were recorded hourly from July 8 to November 13 during the summers of 2008 and 2009. Values were averaged monthly for analysis.

\subsection{Statistical Analysis}

Data were subjected to analysis of variance using proc mixed with SAS statistical analysis software (SAS version 9.3, SAS Institute Inc., Cary, NC). Treatment effects on plant growth and development were evaluated as randomized complete block designs with a split-plot arrangement with four weed control methods as wholeplots and four cultivars as subplots with three replications. For weed control and soil conditions, data were evaluated as a randomized complete block design with four weed control treatments and three replications. Years were treated as repeated measures. Months were treated as repeated measures when soil temperature and moisture content were evaluated and were independently evaluated for weed control data.

\section{Results and Discussion}

\subsection{Annual Weed Control}

Only two annual weed species, common lambsquarters (Chenopodium album L.) and yellow foxtail (Setaria glauca L. Beauv.), had consistent populations throughout the experiment. Weed control treatments did not vary in their ability to control common lambsquarters and generally maintained effective control $(>85 \%)$ in both years through September (data not shown). There was a significant year-by-weed control method interaction for yellow foxtail control in July due to differential effectiveness by the herbicide treatment across the two years (Table 1). All weed control options were effective in controlling yellow foxtail in July in 2008. However, in 
Table 1. Effect of weed control treatment on yellow foxtail control during 2008 and 2009.

\begin{tabular}{|c|c|c|c|c|c|}
\hline \multirow[b]{3}{*}{ Weed control method } & \multicolumn{5}{|c|}{ Yellow foxtail control } \\
\hline & \multicolumn{3}{|c|}{------- July ------- } & \multicolumn{2}{|c|}{----- September ----- } \\
\hline & ----- 2008 ----- & \multicolumn{2}{|c|}{----- 2009 ----- } & \multicolumn{2}{|c|}{----- Combined ----- } \\
\hline & ---- \% ---- & \multicolumn{2}{|c|}{---- \% ---- } & \multicolumn{2}{|c|}{---- \% ---- } \\
\hline Landscape fabric & 88.3 & 91.3 & $a^{z}$ & 90.2 & $\mathrm{a}$ \\
\hline Herbicide & 90.0 & 71.3 & $\mathrm{~b}$ & 56.3 & $\mathrm{~b}$ \\
\hline Straw mulch & 88.3 & 90.0 & a & 79.8 & $\mathrm{a}$ \\
\hline Woodchip mulch & 90.0 & 92.5 & $\mathrm{a}$ & 82.7 & a \\
\hline$p>f^{y}$ & ns & \multicolumn{2}{|c|}{$0.0462^{*}$} & \multicolumn{2}{|c|}{$-{ }^{x}$} \\
\hline
\end{tabular}

${ }^{\mathrm{z}}$ Means followed by the same letter(s) are not significantly different according to pairwise students t-tests $(\alpha=0.05) .{ }^{\mathrm{y}}$ Probability of a greater f-value according to an analysis of simple effects on treatment means within years, ns $=$ non-significant at $\alpha=0.05$, ${ }^{*}=$ significance at $\alpha=0.05$. ${ }^{\mathrm{x}}$ No probability of a greater f-value is reported as main effects were analyzed combined over years.

2009 the herbicide treatment had less yellow foxtail control compared to the other treatments. September yellow foxtail control was similar between years, but differed across weed control methods, where plots receiving herbicide had less yellow foxtail control (56\%) late in the season compared to the mulch alternatives (>79\%).

Overall, mulches were at least as effective as the herbicide application in controlling the annual weeds evaluated. These results were expected as similar results were reported by Cregg and Schutzki with landscape shrubs [14]. These findings indicate that mulch is a valid annual weed control option for vineyards in the Upper Midwestern United States.

\subsection{Plant Growth}

Cultivars differed in their combined trunk and cordon establishment. MN 1131 had longer shoots $(258.1 \mathrm{~cm})$ compared to either DM 8521 or St. Croix (207.3 cm and $204.5 \mathrm{~cm}$, respectively) indicating greater progress toward establishment. The applied weed control treatments did not affect the rate of trunk and cordon establishment in the current study (data not shown). Dormant pruning weights also did not differ among weed control treatments or among cultivars in the two studied years (data not shown).

Overall, impacts on growth rate and progress toward vine establishment were caused by cultivar differences and were not attributable to weed control methods. There were no significant deficiencies caused by the alterative weed control measures, thus mulches may be considered acceptable weed control methods in North Dakota vineyards during establishment.

\subsection{Phenology}

St. Croix broke-bud significantly later than DM 8521 and MN 1131 (144.4, 142.4 and 142.1 days, respectively), while MN 1200 did not differ from any other cultivar. The interaction between weed control method and year also showed significant variation (Table 2). When tests of simple effects were used to evaluate the variation within each year, treatments significantly varied in 2009, but not in 2010. In 2009, vines in plots where herbicide was used broke-bud as much as five days earlier than vines in plots treated with mulch. The early bud-break of these vines may lend them more susceptible to late spring frosts in certain years. It was anticipated that the mulches would delay bud-break due to their moisture conserving and soil cooling effects [15]. Though it was expected that mulches would delay bud-break, light colored mulches were anticipated to delay bud-break longer than the black synthetic mulch due to their contrasting albedos. It was anticipated that the landscape fabric would have an intermediate response between bare ground and the natural mulches. The findings of this study suggest that the soil insulating properties maybe more important in determining vine bud-break when compared to the albedo of the material used. The study also suggested that mulched grape vines may have sufficient budbreak delay to avoid spring frost injury in North Dakota in some years. 
Table 2. Effect of weed control treatment on bud-break date during 2009 and 2010.

\begin{tabular}{|c|c|c|c|c|}
\hline & \multicolumn{4}{|c|}{ Bud-break date } \\
\hline & \multicolumn{2}{|c|}{------- 2009 ------- } & \multicolumn{2}{|c|}{----- 2010 ----- } \\
\hline & \multicolumn{2}{|c|}{ Julian days } & \multicolumn{2}{|c|}{ Julian days } \\
\hline Landscape fabric & 145.1 & $a^{z}$ & 140.6 & \\
\hline Herbicide & 141.4 & $\mathrm{~b}$ & 140.5 & \\
\hline Straw mulch & 146.6 & $\mathrm{a}$ & 142.4 & \\
\hline Woodchip mulch & 146.5 & $\mathrm{a}$ & 140.5 & \\
\hline $\mathrm{p}>\mathrm{f}^{\mathrm{y}}$ & \multicolumn{2}{|c|}{$0.0102^{*}$} & & ns \\
\hline
\end{tabular}

${ }^{\mathrm{z}}$ Means followed by the same letter(s) are not significantly different according to pairwise students t-tests $(\alpha=0.05)$. ${ }^{\mathrm{y}}$ Probability of a greater f-value according to an analysis of simple effects on treatment means within years, ns = non-significant at $\alpha=0.05,{ }^{*}=$ significance at $\alpha=0.05$.

\subsection{Bud Hardiness}

Cultivars and weed control methods did not differ for winter hardiness in the 2009 and 2010 dormant winter live-bud evaluations (data not shown). Though no differences were observed among treatments, large amounts of die back were observed each year in all treatments (>90\% bud death). Significant dieback during the initial seasons after transplanting is not abnormal for the area, however, dieback in vineyards within a $32 \mathrm{~km}$ radius of the experimental site were also greater than average for the winters of 2008/2009 and 2009/2010. In milder winters, different results may be obtained. Based on the results from this study, vine winter hardiness was similar for all weed control treatments, though all vines had large amounts of winter dieback.

\subsection{Soil Conditions}

No differences were detected among weed control treatments for soil water content in any month in any year (data not shown). Differences in soil water contents were expected among treatments as the mulch treatments should conserve moisture. However, Hostetler et al. found inconsistent results for the ability of black geotextile as well as woodchip mulch to increase soil moisture content over clean cultivation in a "Pinot Noir" vineyard [16].

A significant three-way interaction was found for fall average soil temperature between year, month, and weed control method (Table 3). Overall, soil temperatures were warmer in 2008 when compared to 2009. In both years, herbicide treated plots were among the warmest in July. By October, in both years, herbicide treated plot temperatures had decreased to be among the lowest of the tested weed control methods. In 2008, differences between weed control methods in their effect on soil temperatures were larger than was seen in 2009, particularly in July and August. In 2008, landscape fabric and mulch treated plots had cooler temperatures when compared to herbicide treated plots in July and August. In 2009, these three treatments did not differ during these months. Similarly, straw treated plots had significantly lower temperatures in July and August of 2008 when compared to the three other methods, however, did not differ from the landscape fabric or woodchip mulch treated plots in 2009. In November of 2008, woodchip treated plots had higher soil temperatures when compared to herbicide treated plots, however, in 2009 these treatments did not differ.

In both years, soil temperatures within the herbicide treated plots declined more rapidly compared to other plots as they were among the warmest temperatures in August and among the coolest in November. These results were similar to those obtained by Hostetler et al. in 2007 [16]; however, in the current study, all mulching methods tended to moderate soil temperatures when compared to a bare soil control. Hostler et al. found that geotextile based mulching agents were not as effective as woodchip mulch and reflected the soil temperature pattern of a periodically cultivated bare soil check [16]. The current study's results support the tendency of herbicide treated plots' soil temperatures to have a more direct relationship with local air temperatures, whereas mulched plots were more insulated to ambient conditions [17].

Generally, landscape fabric and woodchip mulch tended to perform similarly, having high August temperatures and the ability to retain higher soil temperatures later into the season. Herbicide treated plots had high August temperatures with less ability to retain temperatures later in the season, and tended to more directly follow 
Table 3. Effect of weed control treatment on soil temperature during 2008 and 2009.

\begin{tabular}{|c|c|c|c|c|c|c|c|c|c|c|}
\hline \multirow{4}{*}{$\begin{array}{c}\begin{array}{c}\text { Weed control } \\
\text { method }\end{array} \\
\text { Landscape fabric }\end{array}$} & \multicolumn{10}{|c|}{2008 soil temperature } \\
\hline & \multicolumn{2}{|c|}{ July } & \multicolumn{2}{|c|}{ August } & \multicolumn{2}{|c|}{ September } & \multicolumn{2}{|c|}{ October } & \multicolumn{2}{|c|}{ November } \\
\hline & \multicolumn{10}{|c|}{ 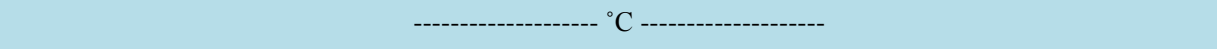 } \\
\hline & 22.6 & $b^{\mathrm{z}}$ & 22.8 & $\mathrm{~b}$ & 17.6 & $\mathrm{a}$ & 10.1 & a & 7.3 & a \\
\hline Herbicide & 25.5 & a & 25.0 & a & 16.6 & $\mathrm{ab}$ & 8.9 & $\mathrm{~b}$ & 5.6 & b \\
\hline Straw mulch & 19.9 & c & 20.4 & c & 16.1 & $\mathrm{~b}$ & 9.5 & $\mathrm{ab}$ & 6.6 & $\mathrm{ab}$ \\
\hline Woodchip mulch & 21.7 & $\mathrm{~b}$ & 22.2 & $\mathrm{~b}$ & 17.5 & $\mathrm{a}$ & 10.5 & a & 7.0 & $\mathrm{a}$ \\
\hline$p>f^{y}$ & \multicolumn{2}{|c|}{$<0.0001^{*}$} & \multicolumn{2}{|c|}{$<0.0001^{*}$} & \multicolumn{2}{|c|}{$0.0302^{*}$} & \multicolumn{2}{|c|}{$0.0469^{*}$} & \multicolumn{2}{|c|}{$0.0229^{*}$} \\
\hline \multirow{3}{*}{$\begin{array}{l}\text { Weed control } \\
\text { method }\end{array}$} & \multicolumn{10}{|c|}{2009 soil temperature } \\
\hline & \multicolumn{2}{|c|}{ July } & \multicolumn{2}{|c|}{ August } & \multicolumn{2}{|c|}{ September } & \multicolumn{2}{|c|}{ October } & \multicolumn{2}{|c|}{ November } \\
\hline & \multicolumn{10}{|c|}{ 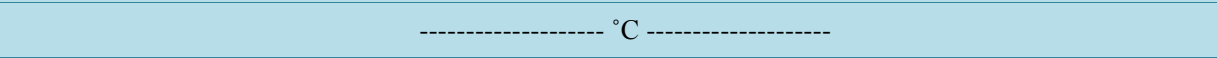 } \\
\hline Landscape fabric & 19.7 & $\mathrm{ab}$ & 19.8 & & 16.1 & & 8.8 & a & 7.0 & $\mathrm{a}$ \\
\hline Herbicide & 22.0 & $\mathrm{a}$ & 19.8 & & 17.4 & & 6.1 & $\mathrm{~b}$ & 4.5 & b \\
\hline Straw mulch & 18.5 & b & 18.6 & & 17.0 & & 7.0 & $\mathrm{ab}$ & 4.7 & b \\
\hline Woodchip mulch & 20.2 & $\mathrm{ab}$ & 20.4 & & 18.0 & & 8.9 & a & 6.4 & $\mathrm{ab}$ \\
\hline$p>f$ & \multicolumn{2}{|c|}{$0.0116^{*}$} & \multicolumn{2}{|c|}{ ns } & \multicolumn{2}{|c|}{ ns } & \multicolumn{2}{|c|}{$0.0186^{*}$} & \multicolumn{2}{|c|}{$0.0337^{*}$} \\
\hline
\end{tabular}

${ }^{\mathrm{z}}$ Means followed by the same letter(s) are not significantly different according to pairwise students t-tests $(\alpha=0.05) .{ }^{\mathrm{y}}$ Probability of a greater f-value according to an analysis of simple effects on treatment means within years, ns = non-significant at $\alpha=0.05,{ }^{*}=$ significance at $\alpha=0.05$.

ambient temperatures compared to plots receiving some kind of mulch. Indirectly, this may be beneficial for woody plants with a temperature dependent acclimation process for winter dormancy, and may partially explain the delay reported for bud-break in 2009, though no soil temperature data was taken during the spring [18]. Alternatively, this effect may be deleterious if it shortens an already short growing season by delaying early vine growth, or delaying acclimation to winter in the fall, though these were not supported by the presented vine establishment data or bud hardiness data of this study.

\section{Conclusion}

Results suggest that any of the three mulches could be used for annual weed control in northern vineyards during establishment as they offered at least as much weed control as the herbicide control and did not adversely affect vine establishment. However, continued research is needed to determine if mulches will alter fruit yield and quality upon vine maturation and together influence winter dieback of vines in the region.

\section{Acknowledgements}

We acknowledge the assistance of James Loken, Sara Gegner, and Grant Mehring in plot setup and data collection, as well as the technical support of Collin Auwarter.

\section{References}

[1] Balerdi, C.F. (1972) Weed Control in Young Vineyards. American Journal of Enology and Viticulture, 23, 58-60.

[2] Shaulis, N.J. and Steel, R.G. (1969) The Interaction of Resistant Rootstock to Nitrogen, Weed Control, Pruning and Thinning Effects on the Productivity of Concord Grapevines. Journal of the American Society for Horticultural Science, 94, 422-428.

[3] Appleton, B.L., Derr, J.F. and Ross, B.B. (1990) The Effect of Various Landscape Weed Control Measures on Soil Moisture and Temperature, and Tree Root Growth. Journal of Arboriculture, 16, 264-268.

[4] Derr, J.F. and Appleton, B.L. (1989) Weed Control with Landscape Fabrics. Journal of Environmental Horticulture, 7, 129-133. 
[5] Smith, M.W., Carroll, B.L. and Cheary, B.S. (2000) Mulch Improves Pecan Tree Growth during Orchard Establishment. HortScience, 35, 192-195.

[6] Skinkis, P (2011) Overview of Vineyard Floor Management. http://www.extension.org/pages/Overview_of_vineyard_floor_management

[7] Dickerson, G.W. (2001) Mulches for Gardens and Landscapes. Guide H-121. New Mexico State University, Las Cruces.

[8] Kohnke, H. and Werkhoven, C.H. (1963) Soil Temperature and Soil Freezing as Affected by an Organic Mulch. Soil Science Society of America Journal, 27, 13-17. http://dx.doi.org/10.2136/sssaj1963.03615995002700010010x

[9] Merwin, I.A., Stiles, W.C. and Van Es, H.M. (1994) Orchard Groundcover Management Impacts on Soil Physical Properties. Journal of the American Society for Horticultural Science, 119, 216-222.

[10] Glover, J.D., Reganold, J.P. and Andrews, P.K. (2000) Systematic Method for Rating Soil Quality of Conventional, Organic, and Integrated Apple Orchards in Washington State. Agriculture, Ecosystems \& Environ, 80, 29-45. http://dx.doi.org/10.1016/S0167-8809(00)00131-6

[11] USDA (2011) Web Soil Survey. http://websoilsurvey.sc.egov.usda.gov/App/WebSoilSurvey.aspx

[12] Fennell, A. (2004) Freezing Tolerance and Injury in Grapevines. Journal of Crop Improvement, 10, 201-235. http://dx.doi.org/10.1300/J411v10n01_09

[13] Goffinet, M.C. (2004) Anatomy of Grapevine Winter Injury and Recovery. Departmental Research Paper, Department of Horticultural Services, Cornell University, Geneva, NY.

[14] Cregg, B.M. and Schutski, R. (2009) Weed Control and Organic Mulches Affect Physiology and Growth of Landscape Shrubs. HortScience, 44, 1419-1424.

[15] Lerner, B.R. (1992) Mulching Conserves Soil Moisture. Purdue University Consumer Horticulture http://www.hort.purdue.edu/ext/mulch.html

[16] Hostetler, G.L., Merwin, I.A., Brown, M.G. and Padilla-Zakour, O. (2007) Influence of Undervine Floor Management on Weed Competition, Vine Nutrition, and Yields of Pinot Noir. American Journal of Enology and Viticulture, 58, 421-430.

[17] Zheng, D., Hunt Jr., E.R. and Running, S.W. (1993) A Daily Soil Temperature Model Based on Air Temperature and Precipitation for Continental Applications. Climate Research, 2, 183-191. http://dx.doi.org/10.3354/cr002183

[18] Arora, R., Rowland, L.J. and Tanino, K. (2003) Induction and Release of Bud Dormancy in Woody Perennials: A Science Comes of Age. HortScience, 38, 911-921. 